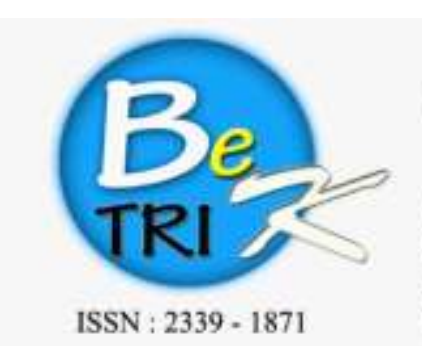

\section{JURNAL ILMIAHBETRIK \\ Besemah Teknologi Informasi dan Komputer}

Editor Office : LPPM Sekolah Tinggi Teknologi Pagar Alam, Jn. Masik Siagim No, 75 Simpang Mbacang. Pagar Alam, SUM-SEL, Indonesia Phone : +62 852-7901-1390.

Email : betrik@lppmsttpagaralam.ac.id / admin.jumal@lppmsttpagaralam.ac.id Website : hitps://ejournal.lppmstipagaralam.ac.id/index.php/betrik/index

\title{
IMPLEMENTASI DATA MINING MENENTUKAN JURUSAN MENGGUNAKAN METODE KLASIFIKASI BERBASIS WEB DI SMA NEGERI 2 MUARA BELITI
}

\author{
Budi Santoso \\ Program Studi Teknik Informatika STMIK MUSIRAWAS Lubuklinggau \\ Jl. Jendral Besar H.M Soeharto KM. 13 Kel. Lubuk Kupang Kec. Lubuklinggau Selatan 1 \\ Kota Lubuklinggau Sumatera Selatan Telp. (0733) 3280300 \\ E-Mail : bdiecayoo@gmail.com
}

\begin{abstract}
Abstrak : Data mining merupakan proses iteratif dan interaktif untuk menemukan pola atau model baru yang sempurna, bermanfaat dan dapat dimengerti dalam suatu database yang sangat besar. Jurusan merupakan salah satu alat ukur kemampuan siswa untuk menentukan arah dan tujuannya kedepan selama dijenjang pendidikan, masalah yang dihadapi dalam menentukan jurusan tersebut yaitu siswa diharuskan untuk melaksanakan tes dan menunggu kurang lebih satu minggu untuk mengetahui hasil yang didapatkan. Tujuan dari penelitian yang dilaksanakan adalah membangun perancangan website menentukan jurusan berbasis web di SMA Negeri 2 Muara Beliti Kabupaten Musi Rawas untuk menyediakan layanan tes dalam menentukan jurusan dan mempermudah pihak sekolah dalam mengelola data siswa, data tes, serta mengelola laporan. Penelitian ini menggunakan metode Klasifikasi Data Mining untuk menganalisis data dan untuk memvisualisasikan pemodelan menggunakan Waterfall Unifed Modelling Languange (UML). Sedangkan bahasa pemrograman menggunakan $P H P, X A M P P$, dan $M Y S Q L$ untuk mengelola database. Penelitian ini menghasilkan data siswa, data soal, serta dapat membantu dalam pengelolaan laporan.
\end{abstract}

Kata Kunci : Data Mining, Klasifikasi, Jurusan, Waterfall, UML, PHP, XAMPP, MYSQL.

\begin{abstract}
Data mining is an iterative and interactive process for finding new patterns or models that are perfect, useful and understandable in a very large database. The department is one measure of the ability of students to determine the direction and purpose for the future as long as education is leveled, a problem faced in determining the direction is that students are required to carry out tests and wait approximately one week to find out the results obtained. The purpose of the research carried out was to build a website design to determine a web-based department at SMA 2 Muara Beliti, Musi Rawas Regency to provide test services in determining majors and facilitate the school in managing student data, test data, and managing reports. This study uses the Data Mining Classification method to analyze data and to visualize modeling using Waterfall Unifed Modeling Language (UML). Whereas programming languages use PHP, XAMPP, and MYSQL to manage databases. This research produces student data, question data, and can assist in the management of reports.
\end{abstract}

Keywords: Data Mining, Classification, Department, Waterfall, UML, PHP, XAMPP, MYSQL. 


\section{PENDAHULUAN}

Perkembangan teknologi informasi telah memberikan kontribusi pada cepatnya pertumbuhan jumlah data yang dikumpulkan dan disimpan dalam basis data berukuran besar. Kebutuhan akan informasi yang akurat sangat dibutuhkan dalam kehidupan sehari-hari, namun kebutuhan informasi yang tinggi kadang tidak diimbangi dengan penyajian informasi yang memadai, seringkali informasi tersebut masih harus digali ulang dari data yang jumlahnya sangat besar. Kemampuan teknologi informasi untuk mengumpulkan dan menyimpan berbagai tipe data jauh meninggalkan kemampuan untuk menganalisis, meringkas dan mengekstrak pengetahuan dari data.

SMA Negeri Muara Beliti adalah Sekolah Menengah Atas Negeri di bawah Dinas Pendidikan Kabupaten Musi Rawas dan salah satu SMA Negeri unggulan yang ada dikabupaten Musi Rawas yang terletak di ibu kota kabupaten Musi Rawas, tepatnya di jalan Lintas Sumatera Km. 10 Muara Beliti Kecamatan Muara Beliti Kabupaten Musi Rawas. SMA Negeri 2 Muara Beliti berdiri berdasarkan Keputusan Gubernur Sumatera Selatan nomor: 377/KPTS/DIKNAS/2004 tanggal 1 April 2004. SMA ini mempunyai fasilitas gedung sekolah dengan jumlah 18 ruang kelas, Ruang Perpustakaan, Laboratorium Kimia, Laboratorium Fisika, Laboratorium Komputer, Laboratorium Biologi , UKS, Mushola dan Sarana Olahraga. SMA Negeri muara beliti ini mempunyai 2 jurusan yaitu IPA dan IPS. Dalam menentukan jurusan membutuhkan waktu yang lama dikarenakan pihak sekolah masih menggunakan cara yang manual, manual disini diartikan bahwa dalam menentukan jurusan pihak sekolah terlebih dahulu harus melakukan tes tertulis yang dilaksanakan digedung sekolah, kemudian setelah tes tertulis dilakukan pihak staff tata usaha harus mengoreksi lembar jawaban siswa apakah sesuai atau tidak dengan kunci jawaban yang sudah disediakan, hal itu dapat menyebabkan terjadinya kesalahan yang seringkali terjadi lebih dari satu atau dua tanpa disadari saat pengoreksian dilakukan dan hal itu dapat merugikan siswa, karena dengan terjadinya kesalahan tersebut siswa seringkali mendapat nilai tes yang berpengaruh dengan minat jurusan yang ia pilih dan pada akhirnya ia tidak bisa masuk kriteria jurusan yang ia pilih.

Saat ini terjadi fenomena yaitu berupa data yang melimpah, setiap hari banyak orang yang berurusan dengan data yang bersumber dari berbagai jenis observasi dengan pengukuran.Misalnya data yang menjelaskan karakteristik data pembelajaran, data yang berasal dari ringkasan hasil eksperimen ilmu pengetahuan.Salah satu aktifitas analisis data adalah klasifikasi atau pengelompokan data ke dalam beberapa kategori/cluster.Ketersediaan informasi dengan adanya sistem untuk menetukan jurusan secara cepat, akurat, dan up to date akan membantu kemudahan dan kelancaran dalam melakukan penentuan jurusan secara maksimal.

Berdasarkan latar belakang yang sudah dijelaskan maka dapat diidentifikasikan permasalahan yang ditemui adalah Proses nilai tes siswa menentukan jurusan sulit, Tingkat 
human error atau kesalahan masih sangat tinggi dan Belum adanya sistem berbasis web yang akan memberikan informasi berisikan pengumuman-pengumuman terutama pengumuman jurusan siswa yang telah melakukan tes.

Tujuan dari penelitian ini adalah Untuk membuat aplikasi data mining menentukan jurusan menggunakan metode apriori di SMA Negeri 2 Muara Beliti sehingga dapat memberikan informasi dengan cepat, akurat dan up to date.

Dari uraian yang ada maka penulis mengambil tema dalam penulisan penelitian ini dengan judul penelitian "Implementasi Data Mining Menentukan Jurusan Menggunakan Metode Klasifikasi Berbasis Web di SMA Negeri 2 Muara Beliti” yang diharapkan dapat membantu mempermudah pengolahan informasi yang lebih efisien berbasis web.

\section{METODOLOGI PENELITIAN}

\subsection{Implementasi}

Implementasi adalah tahap pembuatan program aplikasi berdasarkan perancangan sistem dan basis data yang telah dibuat.[1]

\subsection{Data Mining}

Data mining adalah proses yang memperkerjakan satu atau lebih teknik pembelajaran komputer (machine learning) untuk menganalisis dak mengekstraksi pengetahuan (knowledge) secara otomatis. Definisi lain diantaranya adalah pembelajaran berbasis induksi (induction-based learning) adalah proses pembentukan definisi-definisi konsep umum yang dilakukan dengan cara mengobservasi contoh-contoh spesifik dari konsep-konsep yang akan dipelajari Knowledge Discovery in Database(KDD) adalah penerapan metode saintiik pada data mining. Dalam konteks ini data mining merupakan satu langkah dari proses KDD.[2]

\subsection{Klasifikasi}

Klasifikasi adalah teknik data mining yang paling terkenal.Contoh pengaplikasian, klasifikasi mengandung gambar dan pola yang akurat, diagnosa medis, persetujuan kredit, mendeteksi kesalahan dalam aplikasi industri danmengklasifikasikan trend pasar keuangan. Proses untuk menyatakan salah satu kategori untuk didefinisikan sebelumnya. Proses pembelajaran fungsi target yang memetakan setiap sekumpulan atribut ke salah satu kelas yang didefinisikan sebelumnya.[3]

\subsection{Cluster}

Cluster merupakan metode yang digunakan untuk mempartisi dat set-set menjadi beberapa sub-set atau kelompok sedemkikian rupa sehingga elemen-elemen dari suatu kelompok tertentu memiliki set ptroperti yang dishare bersama dengan tingkat similaritas yang tinggi dalam satu kelompok dan tingkat similaritas antar kelompok yang rendah.[4]

\subsection{Website}

World wide web atau lebih sering dikenal sebagai Web adalah suatu sajian informasi yang menggunakan konsep hyperlink (tautan) yang memudahkan para pemakai komputer yang melakukan browsing atau penelusuran melalui internet. Keistimewaan 
inilah yang telah menjadikan Web sebagai service yang paling cepat pertumbuhannya.[5]

\subsection{Teknik Pengumpulan Data}

Teknik pengumpulan data yang digunakan dalam menyusun penelitian ini adalah sebagai berikut:

\section{Pengamatan (observasi)}

Metode observasi atau pengamatan merupakan salah satu teknik pengumpulan data yang cukup efektif untuk mempelajari suatu sistem. Kegiatan ini bertujuan untuk memperoleh sebuah informasi yang diperlukan dengan cara melakukan pengamatan dan pencatatan langsung ke SMA Negeri 2 Muara Beliti.

\section{Wawancara (interview)}

Adalah suatu teknik yang paling singkat untuk mendapatkan data kepada Guru TU SMA Negeri 2 Muara Beliti.Penelitian ini melakukan wawancara bertujuan untuk mengetahui permasalahan-permasalahan yang ada.

\section{Dokumentasi}

Peneliti meminta beberapa dokumentasi dari Staff TU SMA Negeri 2 Muara Beliti yang berhubungan dengan desain sistem baru.

\subsection{Metode Pengembangan Sistem}

Penelitian ini menggunakan metode pengembangan system dengan metode waterfall.Inti dari metode waterfall adalah pengerjaan dari suatu system dilakukan secara berurutan.[11] :

\section{Analisis Kebutuhan}

Belum adanya sebuah sistem yang digunakan untuk menentukan jurusan di SMA Negeri 2 Muara Beliti belum ada saat ini.

\section{Desain Sistem}

Dalam tahap ini penulis melakukan perancangan sistem menggunakan UML(Use Case Diagram) selain itu penulis juga melakukan perancangan database, perancangan antar muka yang berhubungan dengan input dan output.

\section{Penulisan kode program}

Pada tahap ini penulis membuat dan penulis menterjemahkan hasil perancangan database dengan menggunakan MySQL dengan perancangan antar muka menggunakan bahasa pemrograman $P H P$.

\section{Pengujian Program}

Dalam tahap pengujian ini penulis menggunakan teknik blackbox.

\subsection{Rancangan Sistem}

\subsubsection{Diagram Use Case}

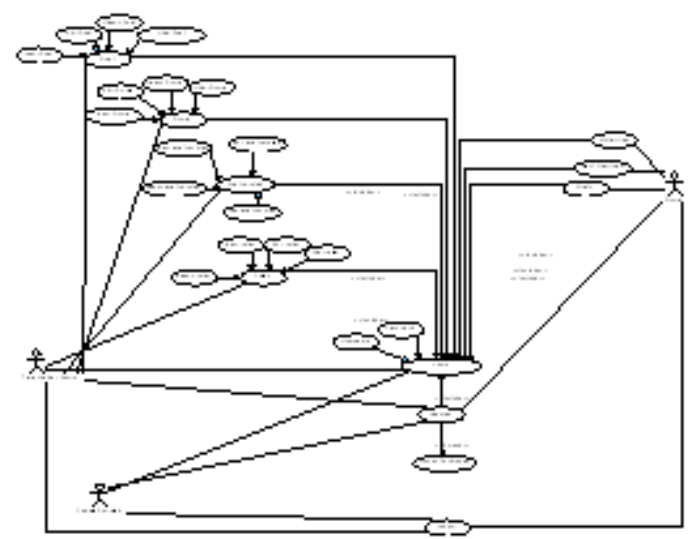

Gambar 1.Diagram Usacase 


\subsubsection{Class Diagram}

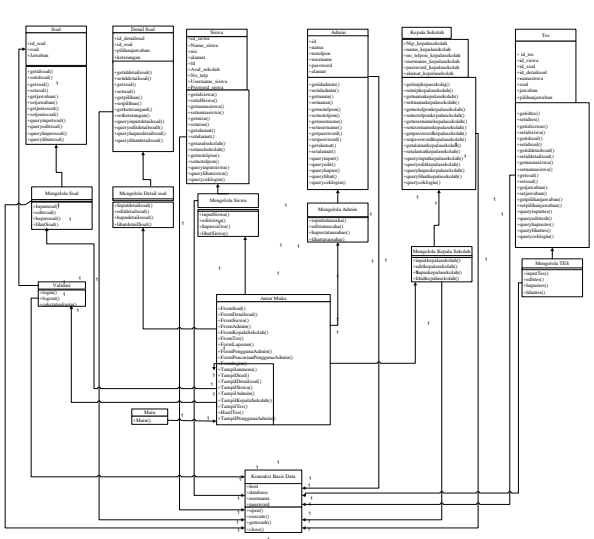

Gambar 2.Class Diagram

\section{HASIL DAN PEMBAHASAN}

\subsection{Hasil Penelitian}

Hasil dari penelitian selama kurang lebih enam bulan di SMA Negeri 2 Muara Beliti, maka hasil yang diperoleh adalah penulis merancang sebuah sistem informasi berbasis website yang dapat diakses oleh semua perangkat yang ada disekolah. Sistem yang berjalan selama ini di tempat tersebut masih menerapkan sistem pencatatan manual dalam pengarsipan data dan menggunakan PC(Personal Conputer) dalam pemrosesan data, dalam hal ini sistem yang akan diterapkan dapat mempermudahdalam melaksanakan tes dan pengolahan pembagian jurusan, cepat dan akurat serta mengantisipasi pihak yang tidak bertanggung jawab dapat merubah atau memanipulasi data tersebut.

\subsection{Pembahasan}

\subsubsection{Halaman Login Admin}

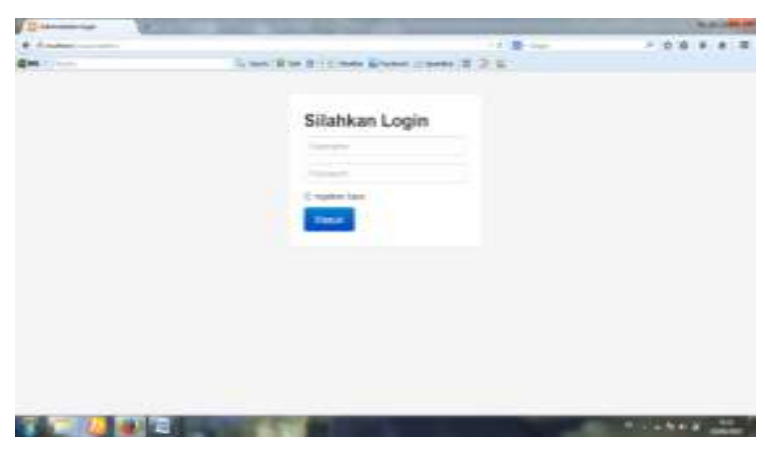

Gambar 3. Tampilan Halaman login

Merupakan halaman login admin, dan kepala sekolah mengakses web maka tampil halaman login admin, dan kepala sekolah menginputkan username dan password lalu tekan button login akan tampil halaman utama admin dan kepala sekolah

\subsubsection{Halaman awal admin}
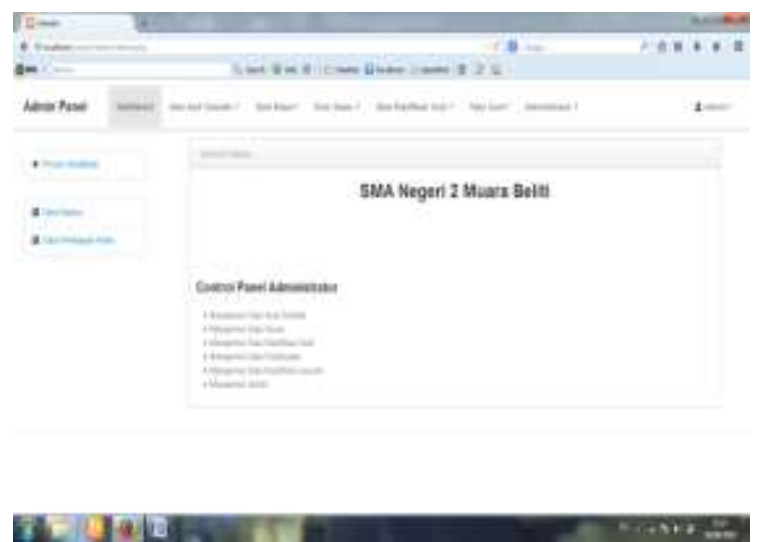

Gambar 4. Tampilan Halaman Utama

Merupakan halaman utama sistem menentukan jurusan yang diakses oleh admin, yang terdiri dari button data asal sekolah, data kelas untuk proses menginput data siswa yang telah dibagi jurusan, menginput data-data siswa yang terdiri nama, tempat tanggal lahir, nis, alamat, asal skolah, jenis kelamin, dan nomor telepon, data klasifikasi soal untuk proses menginput bobot setiap soal yang diujikan, data soal untuk proses menginput soal-soal yang akan 
diujikan untuk siswa, administrator untuk proses penginputan admin jika diperlukan penambahan admin, proses klasifikasi untuk proses pembagian kelas siswa yang telah mengikuti ujian serta untuk melihat laporan dan mencetak laporan.

\subsubsection{Halaman input data sekolah asal}

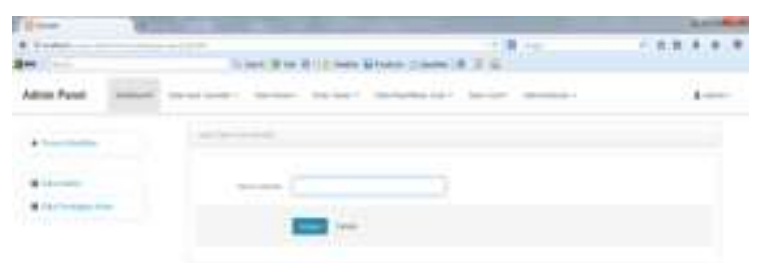

Gambar 5. Tampilan Input Data Sekolah Asal merupakan tampilan halaman untuk menginput data asal sekolah yang menampilkan data-data asal sekolah sesuai dengan data yang diterima dari siswa. Ketika admin mengisi form data sekolah dan menekan button simpan maka akan muncul nama-nama asal sekolah yang telah diinput

\subsubsection{Halaman input data kelas}

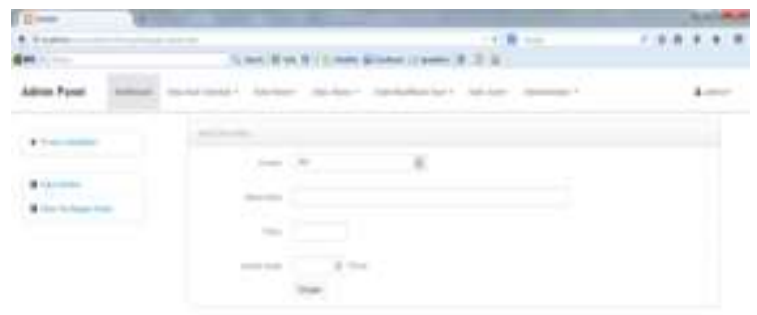

ER Iak

Gambar 6. Tampilan Input Data Kelas

Merupakan tampilan halaman input data kelas yang menampilkan data nama-nama kelas, ketika admin memilih jurusan dan mengisi nama kelas, tahun, dan jumlah kuota maka akan muncul nama-nama kelas serta tahun dan jumlah kuota yang sudah tersedia, admin juga bisa mengedit dan menghapus jika data-data tersebut terdapat kesalahan.

\subsubsection{Halaman Input Data Siswa}

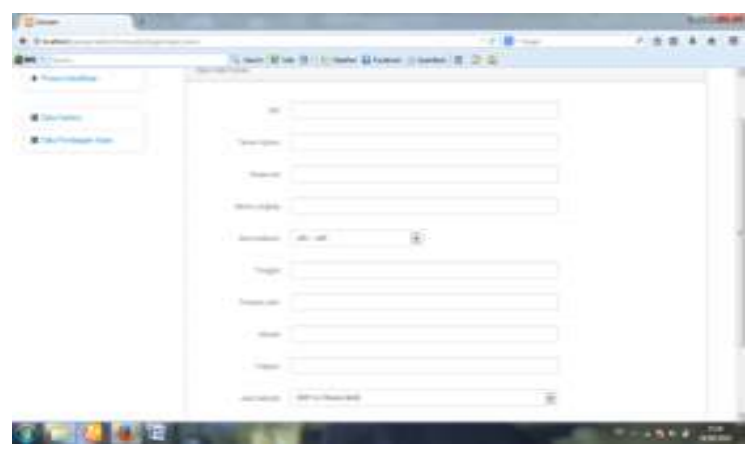

Gambar 7. Tampilan Input Data Siswa

Merupakan tampilan halaman input data siswa yang menampilkan data-data diri siswa, ketika admin mengisi data-data diri siswa dan mengklik button simpan maka akan tersimpan data-data siswa

\subsubsection{Halaman klasifikasi soal}

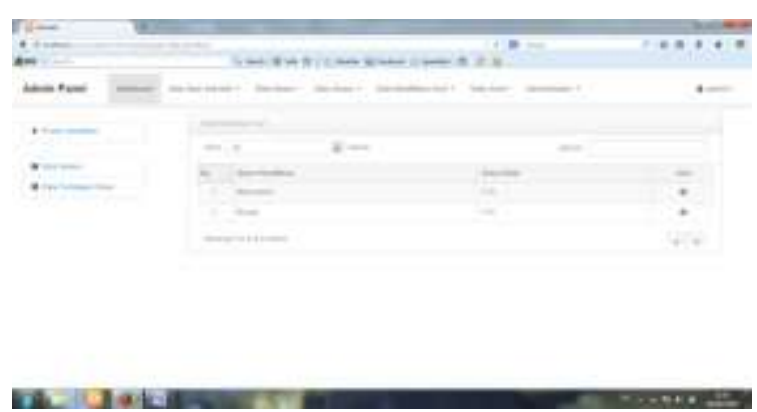

Gambar 8 Tampilan Halaman soal

Merupakan halaman klasifikasi soal, ketika admin mengklik button klasifikasi maka akan muncul nama klasifikasi atau nama soal 
yang akan diujikan serta bobot yang akan diberikan disetiap soal yang benar,

\subsubsection{Halaman Input Data Soal}

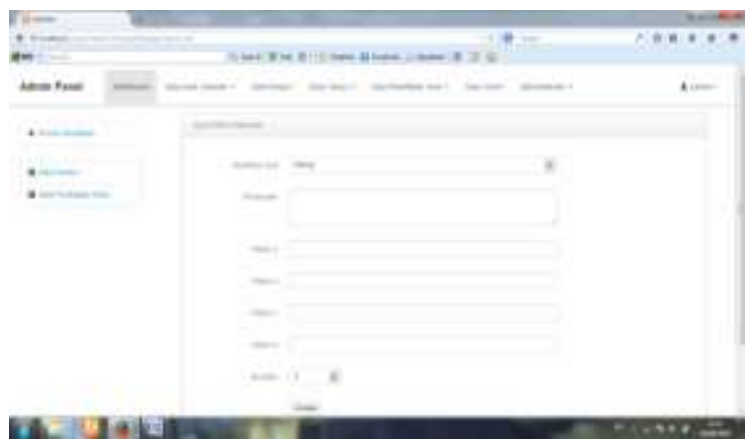

Gambar 9.Tampilan Input Data Soal

Merupakan halaman input soal, ketika admin mengklik button data soal maka akan muncul beberapa kolom klasifikasi soal untuk memilih klasifikasi atau jenis soal, kolom pertanyaan untuk mengisi pertanyaan, kolom jawaban untuk menentukan jawaban atau merupakan kunci jawaban dari soal yang diujikan

\subsubsection{Halaman Proses Klasifikasi Dan Pembagian Data Kelas}

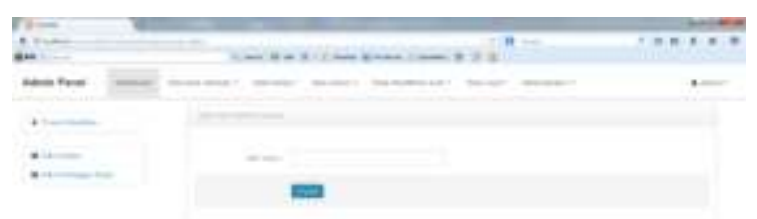

Gambar 10. Tampilan Proses Klarifikasi Merupakan tampilan halaman proses klasifikasi yang menampilkan proses klasifikasi menurut tahun ajaran serta melihat pembagian kelas dan laporan

\subsubsection{Halaman Login Siswa Yang Akan} Mengikuti Tes

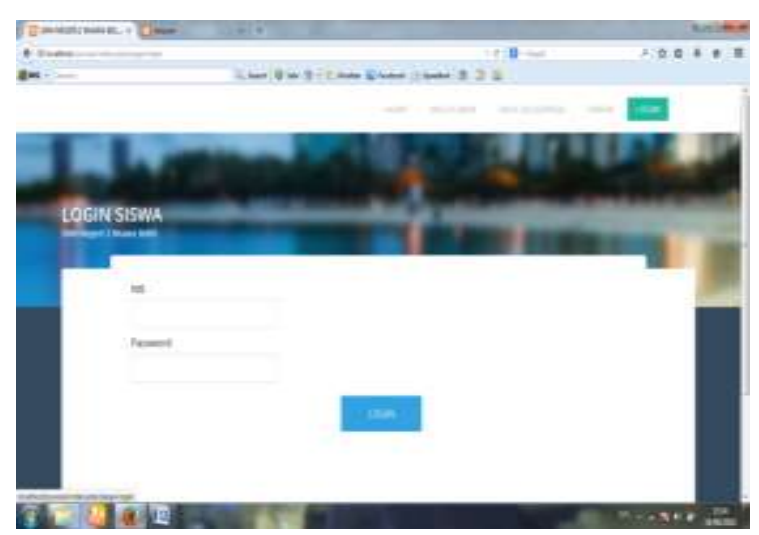

Gambar 11. Tampilan login Siswa

Merupakan tampilan halaman login siswa, ketika siswa mengakses web maka tampil halaman login, untuk masuk dihalaman web siawa terlebih dahulu menginputkan username dan passwordlalu tekan button login, yang mana username berisikan nomor induk siswa atau nis dan password berisikan nama depan siswa.

\subsubsection{Halaman Tes Siswa}

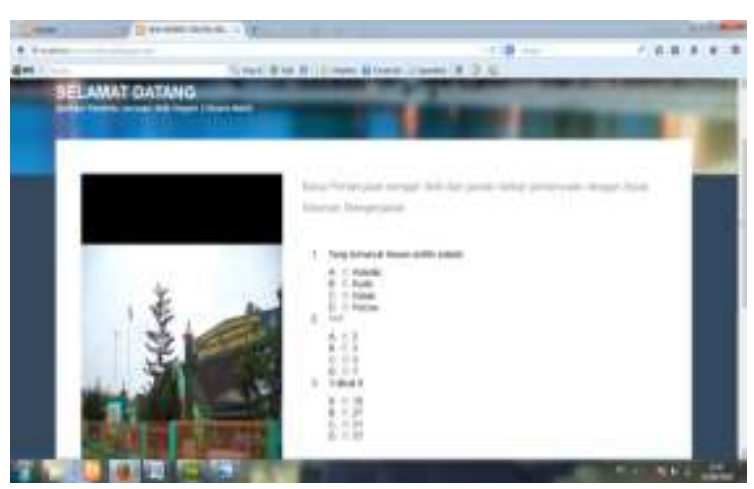

Gambar 12.Tampilan Halaman Tes

Merupakan halaman tes siswa, didalam halaman ini dibagi dalam beberapa soal yang diujikan dengan jenis. 
3.2.11 Halaman Hasil Tes

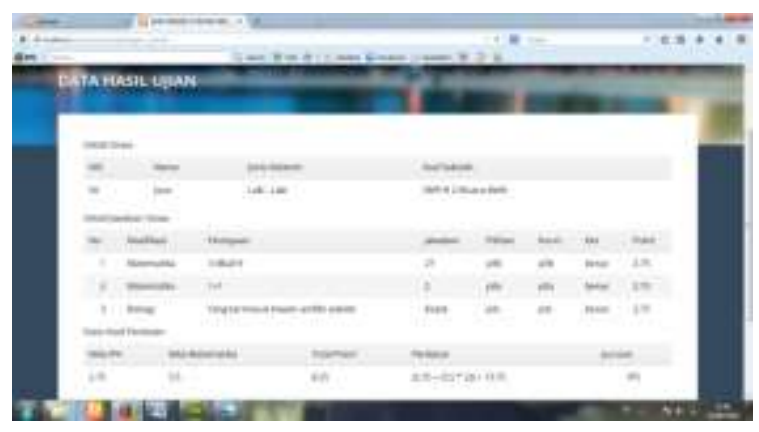

Gambar 13.Tampilan Hasil Tes

Merupakan halaman hasil tes yang dapat diakses oleh siswa setelah siswa melaksanakan tes, ketika siswa telah melakukan tes dengan menjawab pertanyaan-pertanyaan yang telah disediakan.

\subsubsection{Halaman Laporan}

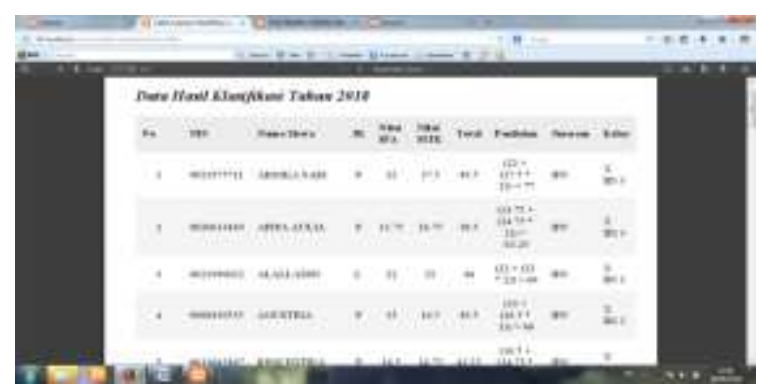

Gambar 14.Tampilan Laporan

Merupakan halaman laporan yang dapat diakses oleh admin, siswa, dan kepala sekolah, dihalaman ini admin, siswa dan kepala sekolah dapat melihat laporan secara keseluruhan.

\subsubsection{Grafik Data Siswa Pertahun}

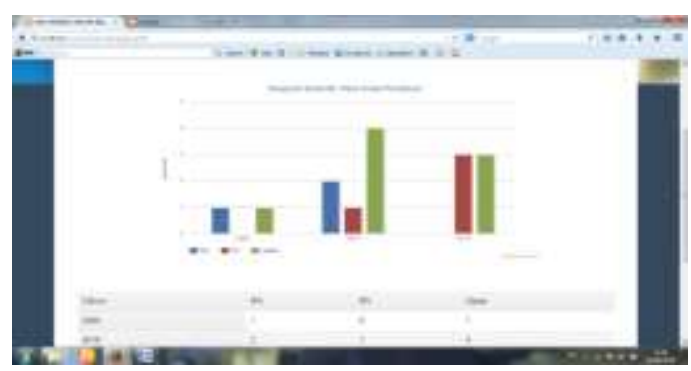

Gambar 15. Tampilan Grafik
Merupakan tampilan halaman grafik yang menampilkan presentase siswa yang masuk diSMA sesuai tahun ajarannya, serta jumlah siswa disetiap jurusan masing-masing sesuai tahun ajarannya.

\section{SIMPULAN}

Berdasarkan pembahasan yang telah dilakukan, maka dapat diambil kesimpulan terhadap: Implementasi Data Mining Menentukan Jurusan Menggunkan Metode Klasifikasi BerbasisWeb (Studi Kasus: SMA Negeri 2 Muara Beliti Kabupaten Musi Rawas) adalah,

1. Dengan adanya Website dapat memudahkan siswa dalam melaksanakan tes dengan cepat tidak perlu menunggu waktu sampai satu minggu untuk mengetahui hasil yang didapat.

2. Dengan adanya Website maka dapat memudahkan pihak sekolah dalam mengelola Laporan Siswa, Laporan Datadata soal, dan Laporan hasil tes siswa.

\section{DAFTAR RUJUKAN}

[1] Jurnal Media Processor, "Penggunaan Algorithma Apriori dalam Menganalisa Prilaku Mahasiswa dalam memilih Mata Kuliah (Studi Kasus: FKIP UPI'YPTK')," Sarjon Defit, vol.8,2013.

[2] Informasi dan Teknologi Ilmiah (INTI), "Implementasi Data Mining Algorithma Apriori pada Sistem Persediaan Alat-alat Kesehatan," Kennedi Tampubolon, Hoga Saragih, Bobby Reza, vol. 1,2013. 
[3] FajarAstutiHermawati, Data Mining. Yogyakarta,2013.

[4] "Penerapan Algorithma Apriori dalam menemukan Hubungan Data Awal Masuk Dengan Data Kelulusan Mahasiswa (Study Kasus :Universitas Darma Persada).” Maulidha Oktaviani p, 2015.

[5] Informasi dan Teknologi Ilmiah (INTI), "Implementasi Data Mining Algorithma Apriori pada Sistem Persediaan Alat-alat Kesehatan," Kennedi Tampubolon, Hoga Saragih, Bobby Reza, vol. 1,2013.

[6] "Penerapan Algorithma Apriori dalam menemukan Hubungan Data Awal Masuk Dengan Data Kelulusan Mahasiswa (Study Kasus :Universitas Darma Persada).” Maulidha Oktaviani p, 2015.

[7] Yosef Murya, PHP menyelesaikan Website 30 juta. 2012.

[8] Abdul Kadir, PEMROGRAMAN DATABASE MYSQL UNTUK PEMULA, $1^{\text {st }}$ ed. Yogyakarta, 2013.

[9] Rosa A.S and M.Shalahuddin, REKAYASA PERANGKAT LUNAK, $4^{\text {th }}$ ed. Bandung, 2016.

[10] Techno Nusa Mandiri,"Clustering Data Nilai Siswa SMA Untuk Penentuan Jurusan Menggunakan Algorithma Fuzzy CMeans," Fajar Akbar, vol 12, 2015.

[11] Dasi,'ImplementasiMetode Fuzzy CMeans dan Topsis Dalaman Membangun system Pendukung Keputusan Penentuan Jurusan SMA (Studi Kasus: Penentuan Jurusan DiSMA Negeri 1 Wonosari)," Anita Budi Astuti, Ema
Utami, Emha Taufiq Luthfi, vol 14, 2013

[12] Its mart," Pemanfaatan Metode KMeans Clustering dalam Penentuan Jurusan Siswa SMA," Chandra Purnamaningsih, Ristu Saptono, Abdul Azis, vol 3, 2014.

[13] Cogito Smart Journal, "Sistem Pendukung Keputusan Penempatan Jurusan Mahasiswa Baru Menggunakan Metode K-Nearest Neighbor, ” Ratih Kumalasari Niswatin, vol 1, 2015. 